\title{
ARTÍCULOS
}

\section{MAPPING MEDIA ACCOUNTABILITY INSTRUMENTS IN SPORTS JOURNALISM}

\section{Mapeo de los instrumentos de rendición de cuentas en el periodismo deportivo}

\section{Xavier Ramon-Vegas and José-Luis Rojas-Torrijos}

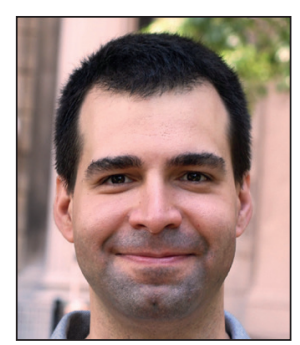

Xavier Ramon-Vegas is a lecturer and researcher in the Department of Communication of Pompeu Fabra University (UPF). He has a PhD in Communication, an MA in Advanced Studies in Social Communication and a BA in Audiovisual Communication and Journalism from UPF. His research focuses on media ethics and accountability, sports journalism and Olympic studies. He is a member of the Journalism Research Group (Grup de Recerca en Periodisme) and participates in the project Accountability and media systems in Spain: real impact and good practices in Spanish media (Mineco/Feder, UE, ref: CSO2015-66404-P).

http://orcid.org/0000-0002-4478-5626

Pompeu Fabra University Campus de la Comunicació-Poblenou Roc Boronat, 138. 08018 Barcelona, Spain xavier.ramon@upf.edu

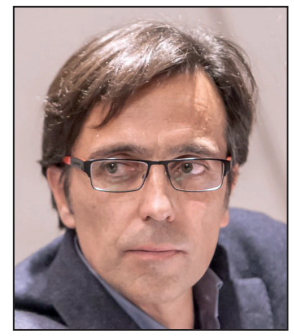

José-Luis Rojas-Torrijos is a lecturer in journalism at the University of Seville and EUSA BusinesS University. He also participates in the MA degree programme in Institutional Communication and Politics at the Univ. of Seville, and in the MA degree programme in journalism and sports communication of the Pontifical University of Salamanca. He holds a PhD in Journalism (2010) and a BA in Information Sciences (1994) from the Univ. of Seville. His research focuses on sports journalism and stylebooks. He is a member of the group Media studies for quality journalism.

http://periodismodeportivodecalidad.blogspot.com

http://orcid.org/0000-0002-7390-9843

University of Seville, Faculty of Communication Avda. Américo Vespucio, s/n. Isla de la Cartuja. 41092 Sevilla, Spain jlrojas@us.es

\begin{abstract}
Sports journalism has been characterized by a series of ethical deficiencies that have challenged the normative standards of the profession. Media accountability instruments can play an invaluable role in addressing these shortcomings. With this in mind, this article identifies and examines the most relevant accountability instruments in the field of sports journalism, including those produced within media organizations and those created outside of them. The researchers have scrutinized the specialized codes in this area and the stylebooks promoted by major sports media, as well as the recommendations proposed by news agencies, general information outlets and key stakeholders worldwide. Innovative practices such as chats, social media, online ombudsmen, observatories and blogs have also been identified as positive examples of the cultivation of a two-way conversation about the standards for and quality of sports content.
\end{abstract}

\section{Keywords}

Accountability; Sports journalism; News quality; Ethics; Instruments; Systems.

\section{Resumen}

El periodismo deportivo se ha caracterizado por una serie de deficiencias éticas que han soslayado los estándares normativos de la profesión. Los instrumentos de rendición de cuentas pueden jugar un papel valioso para superar estas disfunciones. Teniendo esto en mente, el artículo identifica y examina los mecanismos de rendición de cuentas más relevantes en el ámbito del periodismo deportivo, incluidos aquellos producidos de forma interna y externa a los medios. Los investigadores han inspeccionado los códigos éticos en esta área, los libros de estilo promovidos por los principales medios deportivos y las prescripciones formuladas por las agencias informativas, medios de información generalistas y organismos clave a nivel 
internacional. Prácticas innovadoras como los chats, redes sociales, defensores del lector en línea, observatorios y blogs también se han identificado como ejemplos positivos del cultivo de una conversación bidireccional sobre los estándares y la calidad de los contenidos deportivos.

\section{Palabras clave}

Rendición de cuentas; Periodismo deportivo; Calidad informativa; Ética; Instrumentos; Sistemas.

Ramon-Vegas, Xavier; Rojas-Torrijos, José-Luis (2017). “Mapping media accountability instruments in sports journalism". El profesional de la información, v. 26, n. 2, pp. 159-171.

https://doi.org/10.3145/epi.2017.mar.02

\section{Introduction ${ }^{1}$}

According to their normative public service role (Singer, 2013) and their centrality as architects of the public agenda and transmitters of values in democratic societies, quality media should treat all areas of the news arena, including sports, comprehensively and ethically. In the current landscape, which is characterized by citizen's increasing preoccupation with the ethics of media professionals (Plaisance, 2013), sports journalists should also commit to the generation of high-quality content and the pursuit of excellence in their field.

Given these considerations, in the field of sports journalism, extensive literature has shed light on a series of problem areas that have occurred frequently and that have challenged the normative standards and conventional criteria of the profession. These widespread questionable practices include the blurring of the frontiers between journalistic genres; the pervasiveness of rumour; the "tyranny" of a narrow range of sports; sensationalism; the use of warlike language; the lack of a public service mission; the inequalities in relation to gender, race and disability, and the lack of variation in the news sources employed (Hardin; Whiteside, 2009; Horky; Stelzner, 2013; Rojas-Torrijos, 2011b). As Oates and Pauly (2007, p. 333) emphasize,

"sports coverage routinely violates the ethical norms by which the profession asks to be judged".

All these ethical shortcomings have diminished the credibility of the professionals working in the sports journalism field, an area that is still stigmatized by long-held notions that it is a "toy department" or that it consists of "fans with typewriters" (Rowe, 2007). That is, a section

"divorced from the rigorous constraints applied to other areas of the trade" (Boyle, 2006, p. 12).

To address these shortcomings, sports journalists must gain awareness of their accountability (Wulfemeyer, 1985) and assume that

"sports journalism should not be exempted from scrutiny regarding conventional criteria within the news area" (Rowe, 2007, p. 385).

Accountability is a central concept that entails

"accepting certain responsibilities, tasks and objectives" (Christians et al., 2009, p. 132).
In particular, from the normative approach to journalism studies, media accountability refers to the media's commitment to answer for their professional practice to society at large (Bardoel; D'Haenens, 2004; Harro-Loit, 2015; Pritchard, 2000). According to McQuail (2003, p. 19),
"accountable communication exists where authors (or - ginators, sources, or gatekeepers) take responsibility for the quality and consequences of their publication, orient themselves to audiences and others affected, and respond to their expectations and those of the wider so- ciety".

\section{Media accountability instruments can play an invaluable role in helping journa- lists and users monitor and criticize the quality of sports content}

To be accountable, media organizations should embrace three cornerstone components: self-regulation, transparency and citizens' participation (Ramon-Vegas; Mauri-Ríos; Alcalá-Anguiano, 2016). Based on these elements, media accountability instruments (Bertrand, 2000) can play an invaluable role in helping journalists and users monitor and criticize the quality of sports content.

According to Eberwein et al. (2011, p. 20), media accountability instruments (MAIs) are

"any informal institution, both offline and online, performed by both media professionals and media users, which intends to monitor, comment on and criticize journalism and seeks to expose and debate problems of journalism at the individual, media routines, organizational and extra-media levels".

Thus far, the majority of academic studies on media accountability instruments have focused on the general description of traditional or established tools, such as ethical codes and stylebooks (Alsius, 1999; Aznar, 1999; Hafez, 2002; Himelboim; Limor, 2011; Limor; Himelboim, 2006; Nordenstreng: Hannikainen, 1984; Roberts, 2012), ombudsmen (Evers; Groenhart; Van-Groesen, 2010; Maciá-Barber, 2006; Starck, 2010), letters to the editor (Pastor, 2010), media journalism (Malik, 2004) and other institutional instruments anchored within the profession, such as professional associations (Almiron; Narberhaus; Mauri-Ríos, 2016). Recent studies have 
highlighted how accountability systems have experienced a dramatic evolution in the digital environment, where innovative instruments to hold the media into account, such as online ombudsmen, editorial weblogs, readers' comments, error buttons, observatories or media critique on Facebook and Twitter have vigorously expanded across the board (Craft; Vos; Wolfgang, 2015; Eberwein, 2010; Eberwein et al., 2011; Fengler et al., 2014; Mauri-Ríos; Ramon-Vegas, 2015; Rosique-Cedillo; Barranquero-Carretero, 2016). FinaIly, other contributions within the Media Accountability and Transparency in Europe (MediaAcT) project have examined how journalists perceive and evaluate the impact and effectiveness of both old and new media accountability instruments. More precisely, Fengler et al. (2015) conducted a comparative survey with 1,762 journalists from 14 countries to establish professionals' perceptions of media accountability instruments across Europe.

Regarding sports communication, authors such as Horky and Stelzner (2013) have underlined the discrepancies between the sports journalism field and the ethical norms that should guide the profession. Wulfemeyer (1985) analysed the Ethics guidelines produced by the Associated Press Sports Editors (APSE) and proposed further guidelines to foster the accountability of media professionals in the field. Rojas-Torrijos (2011b) even designed a stylebook intended for Pan-American sports reporters. However, no study to date has provided a map of the existing media accountability instruments in sports journalism. To fill this gap, this article offers an overview of the most relevant established and innovative accountability instruments in this field of specialization.

Despite the social transcendence of sports journalism, few specialized media outlets in this area have stylebooks

\section{Methodology}

The objective of this article has been to identify and analyse the most relevant accountability instruments in the field of sports journalism. Given that the research presents an exploratory overview of the major instruments in this field, the sample could not be determined beforehand. Bearing this aspect in mind, researchers employed a methodology based on snowball sampling (Goodman, 1961). This chainreferral technique is mainly carried out within qualitative research frameworks (Brickman-Bhutta, 2012; Bryman, 2016) and is characterized by the process of identifying experiences that are progressively incorporated into the sample. With the aim of locating the most relevant examples across different media systems and journalism cultures around the world, a transnational approach was pursued for this exploratory work.

First, the researchers gathered all the data provided by previous investigations (Fengler et al., 2014; Rojas-Torrijos, 2011a; Wulfemeyer, 1985) and online resources, with the aim of compiling an initial set of accountability instruments.
Subsequently, the fieldwork consisted of monitoring the Internet during a timeframe of 12 months (October 2015 September 2016) to enhance and complete the initial list and locate the most relevant accountability systems in the field of sports journalism.

Once the relevant accountability systems were identified, the researchers proceeded to examine each one of those instruments using the qualitative content analysis technique (Bryman, 2016). The steps highlighted by Wimmer and Dominick (2000, pp. 141-144) were thoroughly followed. The categories of the analysis included the following:

- instruments produced inside or outside of media,

- description of the specifications for and use of the instruments, and

- evaluation of the mechanisms from the accountability perspective.

Finally, all the detected experiences were classified and categorized.

\section{Results}

The research identified the following accountability instruments, which are classified in two categories: those produced within media organizations and those created outside of them.

\subsection{Instruments produced inside media companies or groups}

The instruments that have been implemented by companies are the following:

- stylebooks promoted by major sports media;

- recommendations regarding sports coverage proposed by agencies and general information outlets;

- online ombudsmen;

- online chats; and

- social networking sites.

This section specifies the characteristics of these instruments and highlights relevant examples positioned within the international context.

Table 1. Media accountability instruments in the field of sports journalism

\section{Produced inside media companies or media groups}

Stylebooks and guidelines promoted by major sports media

Recommendations for sports coverage proposed by agencies and general information outlets

Online ombudsmen

Online chats

Social networking sites

Produced outside media companies or groups

External codes: specialized codes and general codes of media ethics

Recommendations for sports journalists issued by key stakeholders

Other external recommendations

Media observatories and specialized publications in media criticism

Scholars' and citizens' blogs 


\subsubsection{Stylebooks and guidelines promoted by major media}

One of the fundamental accountability instruments is inhouse stylebooks (also known as company editorial guidelines). As a social responsibility instrument, they establish an implicit contract between media professionals and citizens, and they are therefore a crucial component in promoting news quality. The MediaAcT survey project found that European journalists consider stylebooks to be the instruments that have the greatest impact on their professional performance (3.74 out of 5 points) (Fengler et al., 2014).

Despite the social transcendence of sports journalism, few specialized media outlets in this area have stylebooks. In Spain, we highlight Mundo deportivo, the first sports daily newspaper to launch its own stylebook based on a previous study conducted by Josep-Maria Casasús (Mundo deportivo, 1995), and Marca, which published its 358-page handbook in 2012 (González-Palencia; Mendaña, 2012). The defunct football weekly Don balón (2004) also created its own stylebook for internal use. Other media in this country have created stylesheets (Sport, Estadio deportivo or Superdeporte) or have adopted their corporations' stylebooks as a frame of reference.

Among the major sports dailies in Latin America, only two have their own stylebook. In 2000, the Argentinian magazine El gráfico created a handbook for internal use (RojasTorrijos, 2011a). The Brazilian daily Lance (2008) designed a document that includes guidelines for style and the ethics and behaviour of professionals, and it pays particular attention to news sources and the use of the Internet and social networking sites.

One of the only sports outlets that has adapted its stylebook to the new digital environment is Bleacher report.

http://bleacherreport.com/pages/styleguide

As its creators note, it is a

"new resource for a new era: a document designed to keep pace with $24 / 7$ news and to-the-minute information".
It provides guidance on online newswriting and includes a dictionary with more than 300 sporting references. Another American outlet concerned with accountability is Editorial guidelines for standards \& practices (ESPN), which has published its editorial guidelines (ESPN, 2010) and its guidelines for the use of social media (ESPN, 2011). Grantland, which discontinued operations in 2015, elaborated several terminological glossaries.

\section{http://grantland.com/tags/grantland-dictionary}

\subsubsection{Recommendations on sports coverage proposed by agencies and general information outlets}

News agencies and general information outlets worldwide have also proposed recommendations for sports journalists. In Europe, the Reuters sports style guide is one of the key documents available:

http://handbook.reuters.com/index.php?title=Sports_ Style_Guide

This guide offers insights into the coverage and styles of six sports with a long tradition in the United Kingdom (cricket, golf, motor racing, football, tennis and winter sports). The stylebook in Spanish by Deutsche Presse Agentur (DPA), edited in 2006 (Salazar-del-Barrio, 2010), includes a chapter devoted to sports in which the crucial value of rigour and seriousness is highlighted. The need to preserve these core values is also stressed by the code adopted in 2008 by Westdeutsche Rundfunk (Prinzing, 2008), one of the affiliate stations of German public service broadcaster $A R D^{2}$. Similar to the situation in Latin America with Empresa Brasil de Comunicação (2013), other European PSBs (public service broadcasting) such as Raidió Teilifís Éireann (RTÉ, 2012) focus predominantly on the need to guarantee the diversity of sports coverage.

In Spain, RTVE (the Spanish public broadcasting corporation), CCMA (the Catalan corporation of audiovisual media), and Canal Sur (Allas-Llorente; Díaz Salgado, 2004) have specific sections devoted to sports in their in-house handbooks. http://manualdeestilo.rtve.es http://www.ccma.cat/llibredestil

\section{STYLEBOOK}

\section{Dynamic Writers, Dynamic Rules}

Once upon a time, the AP could get away with carving its style commandments in stone. Today, standards have to evolve with the needs of the writers and editors who apply them-which means you've come to the right place, because Bleacher Report has always been in the business of adaptation.

\section{What It Is}

The B/R Stylebook is a new resource for a new era: a document designed to keep pace with $24 / 7$ news and to-the-minute information. Yes, the fundamentals will always be the fundamentals, and diligence will always pay dividends-but diligence is nothing if not the art of attention to detail, and attention to detail means seeing the moral of facts on the ground:

In an age of agile social media, front-runners get ahead by staying on their toes-and flat-footedness is the first step toward the Trash folder of history.

How It Works

B/R's copy gurus have spent years refining a style suited to its digital medium. The Stylebook gathers the fruits of their labor in a single basket, with three discrete sections serving three discrete functions:

Bleacher Report Basics, a brief summary of the site's most important bylaws

The Style Standard Clearinghouse, an essential digest of rules and exceptions

Figure 1. Bleacher report style guide
In complying with their social responsibility as PSBs, those institutions stress the importance of disseminating the positive values associated with sport. Other documents issued by privately owned outlets such as El país (2014), El mundo (2002) and La voz de Galicia (2011) place more emphasis on style and the various genres within sports writing.

Moving on to North America, the Ethical journalism handbook from The New York times (2004, p. 40) outlines three rules (131-333) addressed to the sports department. More precisely, it mentions that journalists should avoid gambling on sports events and serving as scorers and that they should not 


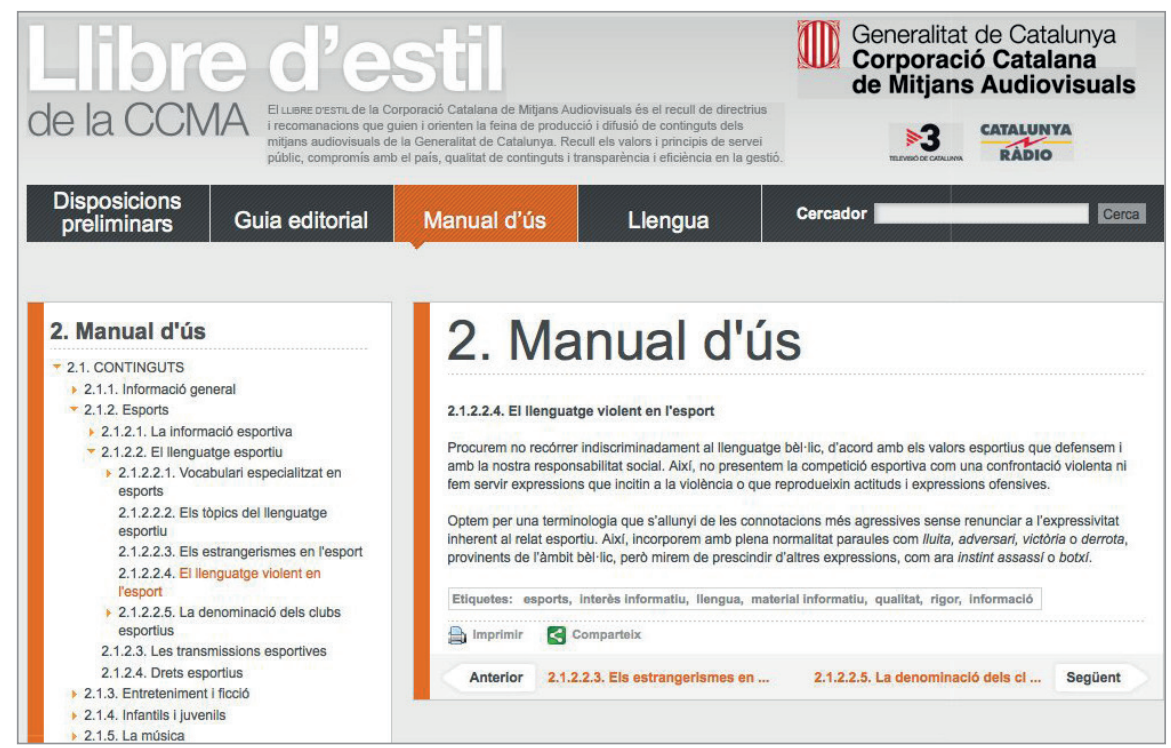

Figure 2. Section devoted to sports in the stylebook of the Catalan Corporation of Audiovisual Media (CCMA)

"accept tickets, travel expenses, meals, gifts or any other benefit from teams or promoters". Further references to conflicts of interest are included in documents issued by US publications such as the

- Los Angeles times

http://latimesblogs.latimes.com/readers/2011/02/latimes-ethics-guidelines.html

- Daily tar heel http://www.dailytarheel.com/page/policies

- Minnesota public radio http://www.mpr.org/about/news_ethics

In the same vein, The Canadian Press advocates that reporters "deliver comprehensive, objective, impartial, accurate, balanced and fair news" (Wenner, 1998, p. 102).

Conversely, other news organizations such as the Associated Press (which has a section entitled Sports guidelines and style) $(A P, 2016)$ and the Columbia Missourian (2009) focus predominately on providing guidance on sports language.

\subsubsection{Ombudsmen}

\section{The ESPN public editor}

The presence of ombudsmen is limited among general information outlets (Maciá-Barber, 2006). While in certain countries such as France, the Netherlands or United Kingdom several media organizations have an ombudsman, this role has not been traditionally enforced in other territories such as Germany. Overall, this instrument has been much more common in the United States than in Eu-

Looking back at Grantland, ESPN

85d- - Jim Brady, Public Editor rope (Starck, 2010). However, it is worth noting that the role of ombudsmen is nearly non-existent in sports media outlets.

The exception can be found in ESPN's public editor, a pioneering post created in 2005 to ensure that the content of the network complies with its Editorial guidelines. The public editor fosters transparency and helps fans understand ESPN's journalistic culture and the editorial criteria behind the content.

http://espn.go.com/blog/ombudsman

He writes a monthly column on the website, reflecting on core aspects such as the loosening of standards with the treatment of ESPN body issue photographs, the use of sponsored content, the criteria employed by the company to select their anchors or the debates about conflict of interest. He also maintains an open forum so that users can send him questions, complaints and suggestions via email or social media about the news and the programming of the network. Afterwards, the public editor gives an answer to those complaints and suggestions on the website, fostering a two-way dialogue with the audiences. Since November 2015, the public editor has been Jim Brady, former sports editor at The Washington post. Previously, the post was occupied by George Solomon (200507), Le Anne Schreiber (2007-2008), Don Ohlmeyer (20092010), The Poynter Institute (2011-2012) and Robert Lipsyte (2013-2014). ESPN indicates that the ombudsman can be appointed for a maximum of 18 months.

Discussions about sports journalism issues by other ombudsmen

Other ombudsmen also reflect on the quality of sports content and give salience to audiences' comments, complaints
FTनII NFL NBA MLB NCAAF Soccer

Watch Listen Fantasy \#: $Q$ Log In

\section{ESPN finally ready to unleash The 63d- Jim Brady, Public Eatitor \\ Investment in esports smart play for 66d-Jim Brady, Public Editc \\ ESPN's merged news structure focuses on quality and speed}

ESPN's merged news structure focuses on quality and speed 33d- - Jim Brady, Public Editic

Lack of transparency on Deflategate made journalism tougher to judge 137d- Jim Brady, Public Editior decision sad, not necessarily wrong 161d - Jim Brady, Public Editior

Your Questions Answered: How 30 for 30 films, SportsCenter anchors are chosen 172d-Jim Brady, Public Editor

ESPN's analysts paid for opinions, not to be objective

igure 3. ESPN public editor

\begin{tabular}{|l|}
\hline$f$ \\
\hline$y$ \\
\hline$D$ \\
\hline$\square$ \\
\hline$\square$ \\
\hline \\
\hline
\end{tabular}

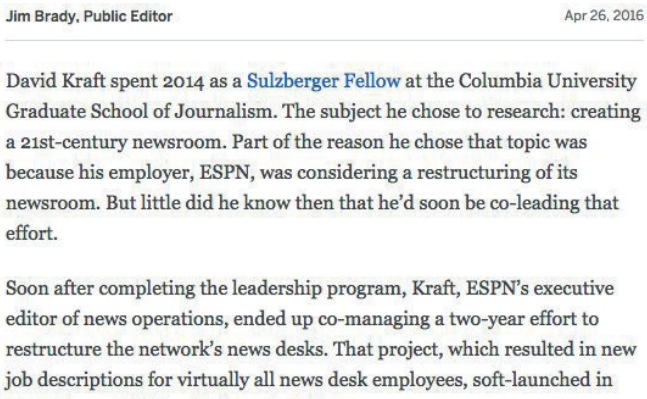

Jim Brady. Public Editor

David Kraft spent 2014 as a Sulzberger Fellow at the Columbia University Graduate School of Journalism. The subject he chose to research: creating a 21st-century newsroom. Part of the reason he chose that topic was because his employer, ESPN, was considering a restructuring of its newsroom. But little did he know then that he'd soon be co-leading that effort.

Soon after completing the leadership program, Kraft, ESPN's executive editor of news operations, ended up co-managing a two-year effort to restructure the network's news desks. That project, which resulted in new job descriptions for virtually all news desk employees, soft-launched in neremher and fully rolled out in .Ianuary 
and criticism. To illustrate, The New York times' former public editor, Margaret Sullivan (2014), expressed readers' concerns about the limited space allocated to women during the NCAA tournament. In the same vein, The guardian's ombudsman discussed sexism in tennis coverage (Elliott, 2014). Edward Schumacher-Matos (2014) wrote about US National Public Radio's decision to pull back on its use of the Washington Redskins nickname. The Canadian Broadcasting Corporation's former ombudsman Kirk LaPointe (2011) discussed issues connected to fairness and balance. El país' ombudsman Lola Galán (2015) remarked on the use of warlike language. These are only a handful of examples that provide a sense of the importance of ombudsmen in discussions of quality and standards in sports journalism.

The presence of ombudsmen is limited among general information outlets and nearly non-existent in sports media outlets, with the exception of ESPN's public editor

\subsubsection{Online chats}

Online chats, which help foster live interaction between readers, editorial teams and experts, have expanded in recent years and have proved to be powerful tools for accountability purposes (Fengler et al., 2014; Mauri-Ríos; RamonVegas, 2015). ESPN's programme Sportsnation has promoted live chats since 2008. All the live conversations can be retrieved at any time from ESPN's website:

\section{http://espn.go.com/sportsnation/chat/archive}

Three illuminating examples reveal the usefulness of these chats for discussing about editorial criteria and handling errors $^{3}$. First, ESPN football reporter Mike Reiss answered readers' questions about journalism ethics, reflecting on why sometimes it is required to grant anonymity to sources, provided that they are "close enough to the story to really know the truth and complete context of the truth". Second, ESPN Southeastern Conference (SEC) blogger Edward Aschoff responded to users' concerns about how does he balance school loyalty with journalistic integrity, stating that he does not root for anyone when covering football. Third, a chat with blogger Andrea Adelson allowed her to acknowledge two factual mistakes in her reporting.

Drawing from this model, several sports-oriented outlets, such as Marca or As regularly hold live meetings with editors, reporters and analysts.

http://www.marca.com/encuentros

http://opinion.as.com/opinion/entrevistas.htm/

Other general information outlets, such as El país, offer chats with the sports editor, but they do not occur on fixed or regular schedule.

http://elpais.com/elpais/entrevistasdigitales.htm/

From time to time, these conversations include enlightening discussions about ethics and editorial criteria. To illustrate, a chat with José Sámano, sports editor of El país, allowed for a discussion on the space allocated to various teams in news reports. The conversation also delved into the need to ensure further controls to avoid hatred language in the online comments posted in sports news ${ }^{4}$. Despite this, consistent with previous findings (Mauri-Ríos; Ramon-Vegas, 2015), this study found a common problem: a vast number of the questions reflect the personal stance of the journalist/editor regarding current news in sports, instead of critically reflecting on the task carried out by media.

\subsubsection{Social networking sites}

Social networking sites are not solely a platform for disseminating sports content, they can also be powerful accountability instruments. According to Fengler et al. (2015, p. 259), there is

"clear evidence that journalists are increasingly aware of, and responding to, comments made by the public on social media platforms".

In fact, journalists are being criticized

"via online MAls (media accountability instruments) more than in many other, more traditional ways" (Fengler et al., 2015, p. 259).

Through Twitter and Facebook accounts, sports media outlets such as Sports illustrated (@SInow), FourFourTwo (@ FourFourTwo) or Mundo deportivo (@mundodeportivo), plus general-information outlets with sports sections, such as the BBC (@BBCSport) or The guardian (@guardian_ sport), handle users' criticism and issue corrections for the content published in their websites and print/audio-visual products. In addition to their general profiles on social media, news organizations have created specific accounts to allow readers to submit their comments, complaints and suggestions. An illustrative example can be found in ESPN's public editor Twitter account.

https://twitter.com/espnpubliced

Through this specific account, Jim Brady has published more than 200 messages, has received suggestions and criticism and has fostered an open-minded debate about balance in sports reporting, the coverage of social and political issues connected to sport or the role of entertainment at ESPN, to list only but a few.

\subsection{Instruments produced outside media companies or groups}

Thus far, this article has examined instruments developed within media companies. This section will focus on presenting instruments developed outside of these organizations: external codes of media ethics, recommendations for sports journalists issued by key stakeholders, other external recommendations, media observatories and blogs.

\subsubsection{External codes}

\section{Specialized codes}

The range of external codes devoted exclusively to sports journalism is fairly limited. The most recognized document is probably the Ethics guidelines promoted by the Associated Press Sports Editors (APSE). The code, created in 1974 and revised in 1991, is built around seven cornerstones that urge journalists to safeguard professional independence, 


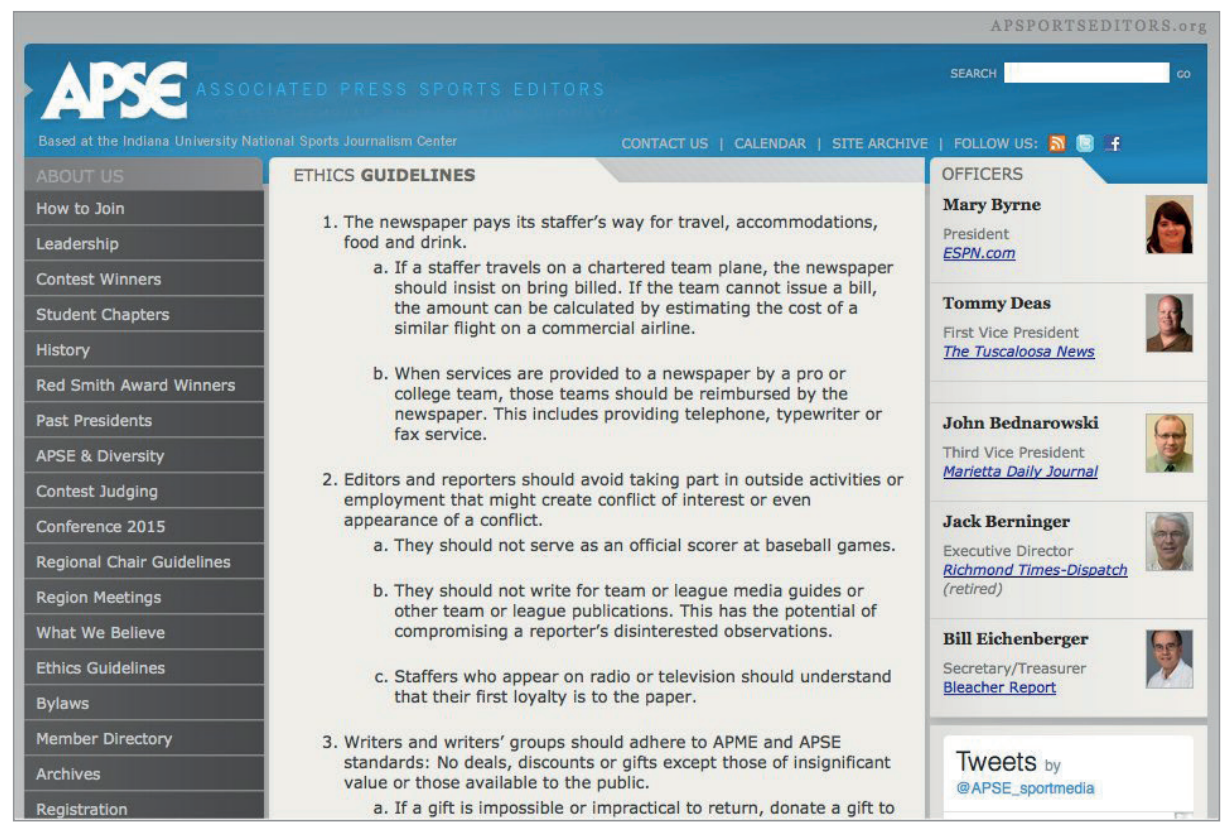

Figure 4. Ethical guidelines of the Associated Press Sports Editors (APSE) by the veteran American sports broadcaster Jimmy Magee. The code, available in English, French and Spanish, provides 13 guiding principles, including the need to be knowledgeable about the law, work with honesty and integrity, provide information about potential conflicts of interest, correct errors and avoid publishing false information. In addition, professionals are reminded about their duty to update their knowledge.

\section{General codes of media ethics}

In addition to specialized codes in sports, professionals can consult the website Accountable journalism created by the Donald W. Reynolds Journalism Institute at the University of verify information, be attentive to sources and avoid gender and race discrimination.

http://apsportseditors.org/apse-ethics-guidelines

The Football Writers Association of America (FWAA) provides recommendations in four areas: the search for truth, minimizing harm, professional independence, and accountability.

http://www.sportswriters.net/fwaa/about/ethics.html

The ethical code of the Automobile Journalists Association of Canada $(A J A C)$ also considers the avoidance of any conflict of interest a cornerstone.

http://www.ajac.ca/web/about/ethics.asp

In the European context, we should highlight the Italian Media and sports code.

http://ethicnet.uta.fi/italy/media_and_sports_code

News agencies, general information outlets and key stakeholders worldwide have also proposed useful recommendations for sports journalists

Drawing from the notion of the social transcendence of sport, this code is organized in six chapters that advocate for justice, dignity and the citizens' right to receive information.

In the German context, the eight guidelines promoted in 2010 by the German association of sports journalists, the Verband Deutscher Sportjournalisten (VDS), are noteworthy. These recommendations emphasize the public function of sports journalism and advocate for non-discrimination. The $V D S$ also highlights the importance of maintaining independence, respecting individuals' privacy and ensuring accuracy (Horky; Stelzer, 2013).

In 2014, the International Press Sports Association (AIPS, 2014) approved its code of professional conduct, supervised
Missouri. The site contains more than 400 general and spe-

http://accountablejournalism.org

\subsubsection{Recommendations for sports journalists written by key stakeholders}

Sports journalists can also review the recommendations issued by key stakeholders in the world of sport. First, the Byelaw to Rule 48 of the $1 O C$ charter reminds professionals that

"the media coverage of the Olympic Games should spread and promote the principles and values of Olympism" (IOC, 2015, p. 92).

Second, Unesco's Sports ethics code (Unesco, 1992), the Code of Sports Ethics (Council of Europe, 1992) and the Charte d'éthique et de déontologie du sport Français (Cnosf, 2012) emphasize the media's responsibility to promote fair play and set a positive example to children and young people. Third, the Code of sports ethics, devised by the Portuguese Institute for Sport and Youth (2015), includes a section on recommendations with regard to objectivity, truth and privacy.

To address the long-standing lack of knowledge of disability sport (Pate; Hardin, 2013), journalists should pay attention to two essential documents. The International Paralympic Committee (2014) created a 18-page document entitled Guide to reporting on persons with an impairment. This easy-to-use guide provides journalists with general rules and a list of preferred terminology and incorrect terms. The British Paralympic Association (2012) published a 5-page reference guide to help professionals use appropriate language. Regarding intellectual disability, the Special Olympics (2014) Style guide is available to professionals.

\subsubsection{Other external recommendations}

Additional recommendations are promoted by institutions that promote the appropriate use of language, such as Funcialized deontological codes from around the world. 
dación del Español Urgente. In 2013, Fundéu created a specific section on the language of football, entitled Liga BBVA del español urgente. Other guidelines can be found in its book El español más vivo (Fundéu, 2015).

http://www.fundeu.es/especiales/liga-del-espanol-urgente

As noted throughout the article, disability and women sport are two sensitive areas that require a higher degree of attention from sports journalists. Regarding disability, along with the recommendations issued by International Paralympic Committee, British Paralympic Association and Special Olympics, governmental institutions have promoted guides for reporting on disability, such as those issued by Junta de Andalucía (Álvarez-Pérez, 2013) and the Spanish Committee of Representatives of Persons with Disabilities (Cermi, 2011). We also highlight the stylebook by Servimedia (Belda-García; Maíllo-Belda; Prieto-Ampudia, 2007). The following three documents should be considered with respect to the coverage of female sport: Guía de lenguaje para el ámbito del deporte (Lledó-Cunill, 2009); Hablamos de deporte. En femenino y en masculino (Alfaro-Garandilla; Bengoechea-Bartolomé; Vázquez-Gómez, 2011); and Deporte y mujeres en los medios de comunicación (López-Díez, 2011).

\subsubsection{Media observatories and specialized publications in media criticism}

Although there are no media watch observatories exclusively devoted to sports journalism, the largest publications related to media criticism around the world examine the good and bad practices of sports media. To illustrate, Columbia journalism review has raised a public debate about anonymous sourcing in NBA trade scoops (Biasotti, 2016). Media matters for America has shown the importance of responsibility in the sporting coverage of transgender individuals (Percelay, 2016). In addition, the Poynter Institute provides resources for reporters who cover LGBT athletes (Klinger, 2014).
The European Journalism Observatory offered a platform for professor Suzanne Franks (2015) to discuss the absence of women in sports journalism. In Spain, Mèdia.cat (2015) has devoted space to reflect on sexism in sports media. In Latin America, Ética segura, created by Fundación Nuevo Periodismo Iberoamericano, regularly promotes debates on Twitter and archives the most relevant messages in Storify. https://storify.com/EticaSegura

Before the Rio 2016 Olympics, it also disseminated a set of guidelines to promote ethical sports coverage.

http://eticasegura.fnpi.org/2016/07/26/decalogo-unacobertura-deportiva-responsable

The range of external codes devoted exclusively to sports journalism is fairly limited

\subsubsection{Scholars' and citizens' blogs}

Other innovative instruments such as scholars' and citizens' blogs also promote reflection on news quality. In Spain, we highlight La buena prensa, and Periodismo deportivo de calidad.

http://labuenaprensa.blogspot.com.es

http://periodismodeportivodecalidad.blogspot.com.es

In the international context, two key examples should be considered: the blogs from the National Sports Journalism Center at Indiana University and the Center for Journalism Ethics at the University of Wisconsin-Madison.

http://sportsjournalism.org

http://ethics.journalism.wisc.edu

The latter provides students and citizens with many materials and resources about journalism ethics. It should be borne in mind that this institution hosted the conference Fair or foul? Ethics in sports journalism in 2015. The event included several sessions that revolved around the conflicts of interest and the editorial and commercial criteria that impact on ethics and quality of content in current sports journalism.

\section{Discussion and conclusions}

The analysis has provided illuminating examples of established and innovative media accountability instruments in the international context that have been created both within and outside media companies. The map that emerges (see figure 6) showcases a great variety of instruments of accountability. The range of resources shown in this article can serve as a "moral compass" (Kovach; Rosenstiel, 2001, p. 181); that is,

Figure 5. Blog of the National Sports Journalism Center at Indiana University 


\section{Traditional}

\section{\begin{tabular}{l|l} 
Specialized codes & Sports media stylebooks
\end{tabular} \\ APSE / AIPS / FWAA / AJAC / VDS / Media and Sports Code $\quad$ Mundo Deportivo / Marca / Don Balón / El Gráfico / Lance \\ Bleacher Report / ESPN / Grantland}

General codes of media ethics

Other external recommendations

Fundéu / Junta de Andalucía / CERMI / Servimedia / CSD

Recommendations by agencies and general outlets Reuters / DPA / ARD / EBC / RTÉ / RTVE / CCMA / Canal Sur

El País / El Mundo / La Voz de Galicia / NYT / Los Angeles Times

Associated Press / Canadian Press / Daily Tar Heel / Missourian

\section{External}

Online observatories and media criticism publications Columbia Journalism Review / Media Matters for America Poynter / EJO / Mèdia.cat / Ética Segura

Scholars' and citizens' blogs La Buena Prensa / Periodismo Deportivo de Calidad National Sports Journalism Center Center for Journalism Ethics

\section{Internal}

Online ombudsmen ESPN Public Editor

General outlets' ombudsmen NYT / The Guardian / NPR / CBC / El País

Online chats

ESPN / Marca / As / El País

Social networking sites

\section{Innovative}

Figure 6. Map of the media accountability instruments examined in the research

a valuable toolkit for professionals. These assets, combined with education and continuing professional development (CPD), can help practitioners increase their self-awareness of the many ethical constraints and practices embedded in journalistic routines. Most importantly, they can ultimately point journalists in the right direction with regard to language and the highest of standards of reporting.

Given the above, a closer scrutiny of the map also reveals that in some areas there are imbalances that should be addressed. First, it is noteworthy that there are only a handful of examples of codes that are specific to sports journalists and that there is a limited range of guidelines devised within and outside media companies. Bearing this in mind, media organizations and external agents (institutions, professional associations, academia), particularly those in countries outside the North Atlantic/liberal model (Hallin; Mancini, 2004), should work harder to create additional recommendations. Those would certainly contribute to improving the credibility of sports journalism and its image of rigour in relation to society.

\section{Chats, social media, online ombudsmen, observatories and blogs are positive examples of the cultivation of a two-way conversation between journalists and users about the standards for and quali- ty of sports content}

Second, it is true that innovative instruments such as ombudsmen, blogs and online chats have been discovered in the sports journalism arena. It is evident that certain organizations such as ESPN have been pioneering various media accountability initiatives. Nevertheless, it is equally true that other tools that have not been detected in this field (editorial videos, open news lists, online broadcasting of newsrooms' meetings, error buttons, and so on) should also be encouraged given the beneficial impact that these instruments could have on journalistic practice. The lack of consistency and the deviation from accountability purposes observed in some instruments (for instance, chats that are driven mainly by opinion rather than criticism of content) should be addressed. Finally, in order to counteract the unawareness of accountability instruments among citizens highlighted by previous research (Alsius; Mauri-Ríos; Rodríguez-Martínez, 2011), the dissemination of information about the existence of all the detected mechanisms should also be enhanced so that users can be fully aware of the usefulness of these mechanisms in monitoring the quality of the journalistic task.

Scholars should remain particularly attentive to the area of accountability in sports journalism. This investigation can serve as a valuable springboard for further inquiry into the accountability instruments detected and analysed here. Future research must monitor and examine the emergence of new accountability systems in the international context. In addition, there is considerable need to assess the impact of accountability instruments among citizens and media professionals. It will be essential to achieve closer links between the industry and users (through the use of surveys, in-depth interviews and other methods) to gain a deeper insight into how these instruments work and to assess how they are perceived by all the agents involved in the sports media environment.

\section{Notes}

1. An early version of this article was presented at the $I A$ MCR Ethics of Society \& Ethics of Communication Working Group $2^{\text {nd }}$ preconference, held at CEU Cardenal Herrera University (Valencia) in July 2016. The contribution was appointed as second best scientific presentation. 
2. Arbeitsgemeinschaft der öffentlich-rechtlichen Rundfunkanstalten der Bundesrepublik Deutschland (ARD).

3. The examples highlighted when discussing ESPN's Sportsnation chats can be found in the following links:

Mike Reiss:

http://www.espn.com/sportsnation/chat/_/id/50130/

patriots-with-mike-reiss

Edward Aschoff:

http://www.espn.com/sportsnation/chat/_/id/38526/ ncaa-fb-with-ed-aschoff

Andrea Adelson:

http://m.espn.com/general/chat/chat?eventld=46012\&page $=0$

4. The example of discussion with José Sámano from El país can be retrieved at:

http://deportes.elpais.com/deportes/2015/10/26/ actualidad/1445851555_221430.html

\section{References}

AIPS (2014). AIPS code of professional conduct standards. http://www.aipsmedia.com/acopcs/AIPS_CODE_OF_ PROFESSIONAL_CONDUCT_STANDARDS.pdf

Alfaro-Garandilla, Elida; Bengoechea-Bartolomé, Mercedes; Vázquez-Gómez, Benilde (2011). Hablamos de deporte. En femenino y en masculino. Madrid: Instituto de la Mujer. ISBN: 9788469390214

http://www.csd.gob.es/csd/estaticos/myd/hablamos_ deporte.pdf

Allas-Llorente, José-María; Díaz-Salgado, Luis-Carlos (2004). Libro de estilo. Canal Sur Televisión y Canal 2 Andalucía. Sevilla: RTVA. ISBN: 8460904539

http://www.canalsur.es/resources/archivos_offline/2010/3/22/ OFF_1269268079994LibrodeestiloCanalSur.pdf

Almiron, Núria; Narberhaus, Marta; Mauri-Ríos, Marcel (2016). "Mapping media accountability in stateless nations: The case of Catalonia". Catalan journal of communication \& cultural studies, v. 8, n. 2, pp. 207-225.

https://doi.org/10.1386/cjcs.8.2.207_1

Alsius, Salvador (1999). Codis ètics del periodisme televisiu. Barcelona: Pòrtic. ISBN: 9788473065702

Alsius, Salvador; Mauri-Ríos, Marcel; Rodríguez-Martínez, Ruth (2011). "Spain: A diverse and asymmetric landscape". In: Eberwein, Tobias; Fengler, Susanne; Lauk, Epp; LeppikBork, Tanja (eds.). Mapping media accountability - in Europe and beyond. Cologne: Herbert Von Halem Verlag, pp. 155-167. ISBN: 9783869620381

AP (2016). The 2016 Associated Press stylebook. New York: Associated Press. ISBN: 9780917360633

Álvarez-Pérez, Rosa (2013). Guía de buenas prácticas sobre personas con discapacidad para profesionales de la comunicación. Sevilla: Junta de Andalucía.

http://www.canalsur.es/resources/archivos/2014/9/18/14 11033496031guia_buenas_practicas_discapacidad.pdf

Aznar, Hugo (1999). Ética y periodismo. Barcelona: Paidós. ISBN: 8449306531
Bardoel, Jo; D’Haenens, Leen (2004). “Media responsibility and accountability: New conceptualizations and practices". Communications, v. 29, n. 1, pp. 5-25.

http://repository.ubn.ru.nl/bitstream/handle/2066/64715/64715. pdf?sequence $=1$

Belda-García, Luís-Miguel; Maíllo-Belda, Juan-Emilio; Prieto-Ampudia, José-María (2007). Periodismo social. El compromiso de la información. Madrid: Servimedia. http://www.servimedia.es/LibroEstilo.pdf

Bertrand, Claude-Jean (2000). Media ethics and accountability systems. London: New Brunswick. ISBN: 978 1560004202

Biasotti, Tony (2016). "Anonymous sourcing and the problem with NBA trade 'scoops'". Columbia journalism review. February 18.

http://www.cjr.org/analysis/sports.php

Boyle, Raymond (2006). Sports journalism: context and issues. London: Sage. ISBN: 9781412907989

Brickman-Bhutta, Christine (2012). "Not by the book: Facebook as a sampling frame". Sociological methods \& research, v. 41, n. 1, pp. 57-88.

https://doi.org/10.1177/0049124112440795

British Paralympic Association (2012). British Paralympic Association guide to reporting on paralympic sport. https://goo.gl/BHChZz

Bryman, Alan (2016). Social research methods (fifth edition). Oxford: Oxford University Press. ISBN: 9780199689453

Cermi (2011). Decálogo para un uso apropiado de la imagen social de las personas con discapacidad. Comité Español de Representantes de Personas con Discapacidad.

https://goo.gl/aaurEy

Christians, Clifford G.; Glasser, Theodore L.; McQuail, Denis; Nordenstreng, Kaarle; White, Robert A. (2009). Normative theories of the media. Journalism in democratic societies. Urbana: University of Illinois Press. ISBN: 9780252076183

Cnosf (2012). Charte d'éthique et déontologie du sport Français. Comité National Olympique et Sportif Français. https://goo.gl/XIsbjM

Columbia Missourian (2009). Columbia Missourian stylebook and a guide to Mid-Missouri.

http://convergence.journalism.missouri.edu/wp-content/ uploads/2009/04/missourian-stylebook.pdf

Council of Europe (1992). The code of sports ethics. Beyond the rules of the game.

https://www.coe.int/t/dg4/epas/resources/texts/code_ en.pdf

Craft, Stephanie; Vos, Tim; Wolfgang, J. David (2015). "Reader comments as press criticism: Implications for the journalistic field". Journalism, v. 17, n. 6, pp. 677-693. https://doi.org/10.1177/1464884915579332

Don Balón (2004). Manual de estilo. Barcelona: Don Balón.

Eberwein, Tobias (2010). "From Woodburg to Blogville and back. Media observation daily press and weblogs". In: 
Eberwein, Tobias; Müller, Daniel (eds.). Journalismus und öffentlichkeit. Wiesbaden: Verlag, pp. 143-165. ISBN: 978 3531157597

Eberwein, Tobias; Fengler, Susanne; Lauk, Epp; LeppikBork, Tanja (eds.) (2011). Mapping media accountability in Europe and beyond. Cologne: Herbert Von Halem Verlag. ISBN: 9783869620381

El mundo (2002). Libro de estilo del diario El mundo. http://www.masmenos.es/wp-content/uploads/2002/01/ librodeestilo_elmundo.pdf

El país (2014). Libro de estilo. Madrid: Aguilar. ISBN: 9786071132697

Empresa Brasil de Comunicação (2013). Manual de jornalismo da EBC. Brasília: EBC.

http://www.ebc.com.br/institucional/sites/_institucional/ files/manual_de_jornalismo_ebc.pdf

Elliott, Chris (2014). "We try to keep out the sexism in covering tennis, but sometimes it's difficult". The guardian, 29 June.

http://www.theguardian.com/sport/2014/jun/29/oh-i-sayred-knickers

ESPN (2010). Editorial guidelines for standards \& practices. http://edge-cache.deadspin.com/deadspin/editorial.pdf

ESPN (2011). Social networking for talent and reporters. http://www.espnfrontrow.com/wp-content/uploads/2011/08/ social-networking-v2-2011.pdf

Evers, Hubb; Groenhart, Harmen; Van-Groesen, Jan (2010). The news ombudsman. Watchdog or decoy? Diemen: AMB. ISBN: 9789079700202

http://www.newsombudsmen.org/wp-content/themes/ sink_ono/documents/Nieuwsombudsman_engels.pdf

Fengler, Susanne; Eberwein, Tobias; Alsius, Salvador; Baisnée, Olivier; Bichler, Klaus; Dobek-Ostrowska, Boguslawa; Evers, Huub; Glowacki, Michal; Groenhart, Harmen; HarroLoit, Halliki; Heikkilä, Heikki; Jempson, Mike; Karmasin, Matthias; Lauk, Epp; Lönnendonker, Julia; Mauri, Marcel; Mazzoleni, Gianpietro; Pies, Judith; Porlezza, Colin; Powell, Wayne; Radu, Raluca; Rodríguez-Martínez, Ruth; RussMohl, Stephan; Schneider-Mombaur, Laura; Splendore, Sergio; Väliverronen, Jari; Vera-Zambrano, Sandra (2015). "How effective is media self-regulation? Results from a comparative survey of European journalists". European journal of communication, v. 30, n. 3, pp. 249-266.

http://dx.doi.org/10.1177/0267323114561009

Fengler, Susanne; Eberwein, Tobias; Mazzoleni, Gianpietro; Porlezza, Colin; Russ-Mohl, Stephan (2014). Journalists and media accountability. An international study of news people in the digital age. New York: Peter Lang Publishing. ISBN: 9781433122811

Franks, Suzanne (2015). "Why are there (almost) no women in sports journalism?". European journalism pbservatory. October 5.

http://en.ejo.ch/specialist-journalism/why-are-therealmost-no-women-in-sports-journalism

Fundéu (2015). El español más vivo. 300 recomendacio- nes para hablar y escribir bien. Madrid: Espasa. ISBN: 978 8467044263

Galán, Lola (2015). “¿Militarizamos el deporte?”. El país, 25 septiembre.

http://blogs.elpais.com/defensor-del-lector/2015/09/ militarizamos-el-deporte.html

González-Palencia, Rafael; Mendaña, José-Carlos (2012). Marca - Libro de estilo. Madrid: La esfera de los libros. ISBN: 9788499707952

Goodman, Leo A. (1961). "Snowball sampling". The annals of mathematical statistics, v. 32, n. 1, pp. 148-170.

https://doi.org/10.1214/aoms/1177705148

Hafez, Kai (2002). "Journalism ethics revisited: a comparison of ethics codes in Europe, North Africa, the Middle East, and Muslim Asia". Political communication, v. 19, n. 22, pp. 225-250.

http://www.tandfonline.com/doi/pdf/10.1080/10584600252907461 https://doi.org/10.1080/10584600252907461

Hallin, Daniel C.; Mancini, Paolo (2004). Comparing media systems: three models of media and politics. Cambridge: Cambridge University Press. ISBN: 9780521543088

Hardin, Marie; Whiteside, Erin (2009). "Token responses to gendered newsrooms. Factors in the career-related decisions of female newspaper sports journalists". Journalism, v. 10, n. 5, pp. 627-646.

https://doi.org/10.1177/14648849090100050501

Harro-Loit, Halliki (2015). "'Journalists' views about accountability to different societal groups". Journal of media ethics: Exploring questions of media morality, v. 30, n. 1, pp. 31-43. http://www.tandfonline.com/doi/pdf/10.1080/08900523.2 014.985296

Himelboim, Itai; Limor, Yehiel (2011). “Media institutions, news organizations, and the journalistic social role worldwide: A cross-national and cross-organizational study of codes of ethics". Mass communication \& society, v. 14, n. 1, pp. 71-92.

https://goo.gl/V8ZWOf

http://dx.doi.org/10.1080/15205430903359719

Horky, Thomas; Stelzner, Brian (2013). "Sports reporting and journalistic principles". In: Pedersen, Paul M. (ed.). Routledge handbook of sport communication. Abingdon: Routledge, pp. 118-127. ISBN: 9780415518192

IOC (2015). Olympic charter. International Olympic Committee. https://stillmed.olympic.org/Documents/olympic_charter_ en.pdf

International Paralympic Committee (2014). Guide to reporting on persons with an impairment.

https://www.paralympic.org/sites/default/files/document/ 141027103527844_2014_10_31+Guide+to+reporting+on+ persons+with+an+impairment.pdf

Klinger, Lauren (2014). "Resources for reporters on all beats (including sports) who cover LGBT people". Poynter.org, August 27.

http://www.poynter.org/2014/resources-for-reporters-onall-beats-including-sports-who-cover-lgbt-people/266165 
Kovach, Bill; Rosenstiel, Tom (2001). The elements of journalism. What newspeople should know and the public should expect. New York: Three Rivers Press. ISBN: 978 0609607831

La voz de Galicia (2011). Libro de estilo 3.6. http://www.prensaescuela.es/attachments/article/51/ LEVoz\%203.6.pdf

Lance (2008). Manual de redaçao e estilo do Lance. Rio de Janeiro: Lance Editora. ISBN: 9788588651104

LaPointe, Kirk (2011). "Hockey night in Canada. Review from the office of the ombudsman, English services". Ombudsman $C B C$, October 26.

http://www.ombudsman.cbc.radio-canada.ca/en/ complaint-reviews/2011/hockey-night-in-canada

Limor, Yehiel; Himelboim, Itai (2006). "Journalism and moonlighting: An international comparison of 242 codes of ethics". Journal of mass media ethics, v. 21, v. 4, pp. 265-285. https://goo.gl/hdhtdN https://doi.org/10.1207/s15327728jmme2104_4

Lledó-Cunill, Eulàlia (2009). Guía de lenguaje para el ámbito del deporte. Vitoria: Emakunde/Instituto Vasco de la Mujer. ISBN: 9788489630178

https://goo.gl/Kd1dF0

López-Díez, Pilar (2011). Deporte y mujeres en los medios de comunicación. Sugerencias y recomendaciones. Madrid: Consejo Superior de Deportes. ISBN: 9788469493663 http://www.csd.gob.es/csd/estaticos/myd/web-guiammcc-vp.pdf

Maciá-Barber, Carlos (2006). La figura del defensor del lector, del oyente y del telespectador. Madrid: Universitas. ISBN: 9788479911928

Malik, Maja (2004). Journalismus-journalismus. Funktion, Strukturen und Strategien der journalistischen Selbstthematisierung. Wiesbaden: VS Verlag für Sozialwissenschaften. ISBN: 9783531142050

Mauri-Ríos, Marcel; Ramon-Vegas, Xavier (2015). “Nuevos sistemas de rendición de cuentas de la información periodística. Una exploración del escenario online español". El profesional de la información, v. 24, n. 4, pp. 380-389. https://doi.org/10.3145/epi.2015.jul.04

McQuail, Denis (2003). Media accountability and freedom of publication. New York: Oxford University Press. ISBN: 978 0198742517

Mèdia.cat (2015). "La premsa esportiva humilia les esportistes". Mèdia.cat, 17 novembre.

http://www.media.cat/2015/11/17/la-premsa-esportivahumilia-les-esportistes

Mundo deportivo (1995). Libro de estilo. Barcelona: El Mundo Deportivo.

Nordenstreng, Kaarle; Hannikainen, Lauri (1984). The mass media declaration of Unesco. Norwood, New Jersey: Ablex. ISBN: 9780893910778

Oates, Thomas P.; Pauly, John (2007). "Sports journalism as moral and ethical discourse". Journal of mass media ethics: Exploring questions of media morality, v. 22, n. 4, pp. 332-347. https://goo.gl/8fZ8OH https://doi.org/10.1080/08900520701583628

Pastor, Lluís (2010). Teoría de las cartas al director. La gestión periodística del público. Barcelona: UOC. ISBN: 978 8497887571

Pate, Joshua R.; Hardin, Robin L. (2013). "Best practices for media coverage of athletes with disabilities". In: Pedersen, Paul M. (ed.). Routledge handbook of sport communication. Abingdon: Routledge, pp. 359-367. ISBN: 9780415518192 https://doi.org/10.4324/9780203123485.ch36

Percelay, Rachel (2016). "Sports illustrated's Caitlyn Jenner cover story shows the importance of transgender visibility". Media matters for America, June 29.

https://goo.gl/CnxnPc

Plaisance, Patrick-Lee (2013). Media ethics. Key principles for responsible practice ( $2^{\text {nd }}$ ed.). Thousand Oaks, California: Sage. ISBN: 9781452258089

Portuguese Institute for Sport and Youth (2015). Code of sports ethics. Lisbon: IPDJ. ISBN: 9789898330062 http://www.pned.pt/media/31485/Code-of-Sports-Ethics. $p d f$

Prinzing, Marlis (2008). "Sports and the media: kick-off for an initiative to make things better". European journalism observatory, August 8.

http://en.ejo.ch/specialist-journalism/sports-and-the-mediakick-off-for-an-initiative-to-make-things-better?print=print

Pritchard, David (ed.) (2000). Holding the media accountable. Citizens, ethics, and the law. Bloomington: Indiana University Press. ISBN: 9780253213570

Ramon-Vegas, Xavier; Mauri-Ríos, Marcel; Alcalá-Anguiano, Fabiola (2016). "Transparencia informativa, autorregulación y participación del público: Mural.com, Rue89.com y TexasTribune.org" Comunicación y sociedad, v. 25, pp. 101125.

http://www.scielo.org. $m x /$ scielo.php ?script $=s c i$ arttext\&pid=S0188-252X2016000100005

Roberts, Chris (2012). "Identifying and defining values in media codes of ethics". Journal of mass media ethics: Exploring questions of media morality, v. 27, n. 2, pp. 115-129. https://doi.org/10.1080/08900523.2012.669289

Rojas-Torrijos, José-Luis (2011a). Periodismo deportivo de calidad: propuesta de un modelo de libro de estilo panhispánico para informadores deportivos. Madrid: Fragua. ISBN: 9788470744594

Rojas-Torrijos, José-Luis (2011b). Libros de estilo y periodismo global en español. Valencia: Tirant Humanidades. ISBN: 9788493931667

Rosique-Cedillo, Gloria; Barranquero-Carretero, Alejandro (2016). "Radiografía de los observatorios de medios en España. Una herramienta ciudadana para la reforma mediática". Revista latina de comunicación social, 71, pp. 443-469. https://doi.org/10.4185/RLCS-2016-1104 
Rowe, David (2007). "Sports journalism: Still the 'toy department' of the news media?" Journalism, v. 8, n. 4, pp. 385-405.

https://doi.org/10.1177/1464884907078657

RTÉ (2012). Journalism guidelines. Raidió Teilifís Éireann. http://www.rte.ie/documents/about/rte-journalismguidelines-april3-2012.pdf

Salazar-del-Barrio, Juan-Carlos (coord.) (2010). De buena fuente: DPA, servicio internacional en español: medio siglo de historia, medio siglo de noticias. Madrid: Akal. ISBN: 978 8446033226

Schumacher-Matos, Edward (2014). "Changing field: A new guideline on what to call that Washington football team". National public radio, October 14.

https://goo.gl/VZnRVh

Singer, Jane B. (2013). "The ethical implications of an elite press". Journal of mass media ethics: exploring questions of media morality, v. 28, n. 3, pp. 203-216.

http://openaccess.city.ac.uk/3446

https://doi.org/10.1080/08900523.2013.802163

Special Olympics (2014). Special Olympics style guide. http://media.specialolympics.org/soi/files/resources/ Communications/StyleGuide-2014.pdf

Starck, Kenneth (2010). "The news ombudsman: viable or vanishing?". In: Eberwein, Tobias; Müller, Daniel (eds.). Journalismus und öffentlichkeit. Wiesbaden: VS Verlag für Sozia-
Iwissenschaften, pp. 109-118. ISBN: 9783531157597 https://doi.org/10.1007/978-3-531-92006-1_8

Sullivan, Margaret (2014). "As NCAA basketball dominates Times sports section, what about the women's game?". The New York times, March 24.

http://publiceditor.blogs.nytimes.com/2014/03/24/as-nc-a-a-basketball-dominates-times-sports-section-whatabout-the-womens-game/?_r=1

The New York times (2004). Ethical journalism. A handbook of values and practices for the news and editorial departments.

http://www.nytco.com/wp-content/uploads/NYT_Ethical_ Journalism_0904-1.pdf

Unesco (1992). Code of sports ethics.

http://portal.unesco.org/education/en/ev.php-URL_

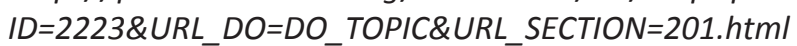

Wenner, Lawrence A. (ed.) (1998). MediaSport. London: Routledge. ISBN: 9780415140416

Wimmer, Roger D.; Dominick, Joseph R. (2000). Mass media research: An introduction ( $6^{\text {th }}$ ed.). New York: Wadsworth Publishing Co. ISBN: 9780534560072

Wulfemeyer, K. Tim (1985). "Ethics in sports journalism: Tightening up the code". Journal of mass media ethics: Exploring questions of media morality, v. 1, n. 1, pp. 57-67. https://goo.gl/tLDo2X http://dx.doi.org/10.1080/08900528509358256

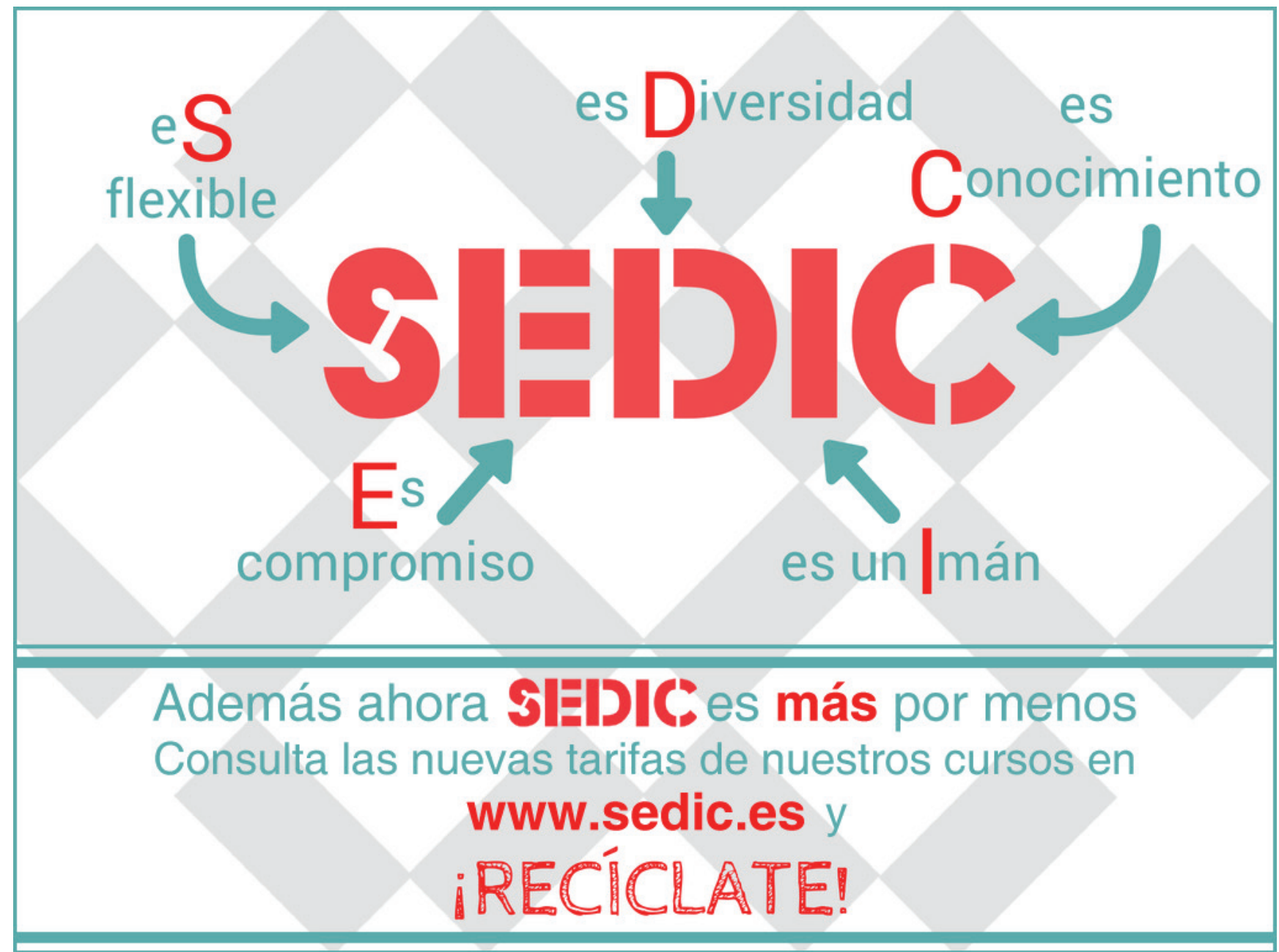

